\title{
Benefits and uses of mushroom
}

Keywords: mushroom, proteins, vitamins, minerals, chitin, essential amino acids, potassium, phosphorus iron, carbohydrates, rhiboflavin

\section{Introduction}

It is estimated that there are around 140,000 species of mushroom on earth, but so far only 10\% (about 14,000) have been named and this number is increasing steadily. ${ }^{1}$ Mushroom, suitable humidity and temperature, under the forest, meadows, organic matter rich in soils, decaying branches and tree fragments are grown on. Mushrooms are prominent in the habitats they spread with the fructification organ in remarkable colors and shapes. With these features, it has attracted the attention of mankind and the methods of using mushrooms have been investigated.

Mushrooms have been used as nutrients by many communities due to their taste and nutritional content. The ancient Romans called "the food of the gods" and the first Egyptians called the "gifts from God of Osiris" and Chinese called it "the elixir of life". ${ }^{2}$ In the history of humanity, mushrooms have been consumed as food, especially during the rainy season. Approximately 1000 species of mushrooms are classified as edible worldwide. ${ }^{3}$

Mushrooms are known as healthy foods throughout the world with proteins, vitamins, minerals, chitin, essential amino acids as well as low fat and calories. ${ }^{4}$ The nutritional value of mushroom is comparable to foodstuffs such as corn, soybeans or beans. They are especially important foods with the basic amino acids they contain. Within the mushrooms, there are proteins at levels ranging from $5-49 \%$ of dry weight. In addition to protein, dietary fibers, minerals such as potassium, phosphorus iron, and vitamins and carbohydrates. ${ }^{4}$

Mushrooms, which serve as a good source of food for human beings for centuries, have high nutritional value due to the vitamins and minerals they contain. In a study on an edible mushroom species, it was found that $88-90 \%$ water, $3-8 \%$ protein, $0-3 \%$ fat, $4-9 \%$ carbohydrate, $1-2 \%$ ash (calcium, phosphorus, iron, copper, chlorine, sodium, zinc, manganese and bromine) in trace amounts; B vitamins A and B complex vitamins B1 (Thiamin), B2 (Rhiboflavin), B3 (pantetonic acid), B5 (Nicotinic acid), vitamins. ${ }^{5}$ Mushrooms are also rich in vitamin $\mathrm{C}$ and vitamin $\mathrm{D}$. Mushroom contain 5-10 times more vitamin B3 than vegetables. The amount of fat is low in protein. It is also a food ingredient recommended for those who do not eat cholesterol because the fat content of mushroom is low. The richness of vitamins is known to have a calming and softening effect on the nervous system of humans. ${ }^{6}$

Mushrooms are quite important natural sources used in alternative medicine. Today, in parallel with the increase in the number of diseases, alternative medicine tendency is gradually increasing due to insufficiency of synthetic medicines in these disadvantages. As an alternative to synthetic drugs, many natural resources such as plants, animals and mushrooms are used. ${ }^{7,8}$

Nowadays, cardiovascular diseases, cancer and chronic diseases that can be caused by aging are gradually increasing. One of the main causes of this increase is thought to be oxidative stress. Antioxidant compounds function as protection mechanisms against damage that may occur in cell systems in living organisms, reduction of oxidative damage and damage. Mushrooms are quite good natural sources for these antioxidant compounds. ${ }^{9}$

Mushroom contains several secondary metabolites, including
Volume 6 Issue 2 - 2018

\author{
Celal Bal \\ Gaziantep University, Oguzeli Vocational School,Turkey
}

Correspondence: Celal Bal, Oguzeli Vocational School, Gaziantep University, Gaziantep, Turkey, Tel +90 5308 7676I I, Email bal@gantep.edu.tr

Received: April 02, 2018 | Published: April 23, 2018

phenolic compounds, polyketides, terpenes and steroids in their structure. These seconder metabolites, which do not have nutritional values, are distinguished by their medical properties. These secondary metabolites play a vital role in the antioxidant defense mechanisms of biological systems. ${ }^{1}$

Previous studies have reported that fungi have antimicrobial, antibacterial, anti-carcinogenic, antioxidant, antiviral, antiinflammatory, anticoagulant, cytotoxic, cytostatic, antiatherogenic, antioxidant, anti-allergic, hypoglycemic and immunosuppressive properties. $^{10-13}$

As a result, mushrooms have been used and used by people for different purposes for centuries. The nutritional characteristics of mushroom, their medical properties and their use in alternative fields will help people to search for natural resources.

\section{Acknowledgements}

None.

\section{Conflict of interest}

The authors declare there is no conflict of interest.

\section{References}

1. Bal C, Akgul H, Sevindik M, et al. Determination of the anti- oxidative activities of six mushrooms. Fresenius Envir Bull. 2017;26:6246-6252.

2. Smith JE, Rowan NJ, Sullivan R. Medicinal Mushrooms: A rapidly developing area of biotechnology for cancer therapy and other bioactivities. Biotechnology Letters. 2002;24(22):1839-1845.

3. Ruan-Soto F, Ordaz-Velázquez M, García-Santiago W, et al. Traditional processing and preservation of wild edible mushrooms in Mexico. Ann Food Process Preserv. 2017;2(1):1013.

4. Valverde ME, Hernández-Pérez T, Paredes-López O. Edible mushrooms: Improving human health and promoting quality life. International Journal of Microbiology. 2015;2015:14

5. Mat A. Türkiyede mantar zehirlenmeleri ve zehirli mantarlar. Nobel Tip Kitabevi; 2000.

6. Vinhal Costa Orsine J, Cavalho Garbi Novaes MR, Ramírez Asquieri E. Nutritional value of Agaricus sylvaticus; mushroom grown in Brazil. Nutricion hospitalaria. 2012;27(2):449-455.

7. Tabbouche S, Gürgen A, Yildiz S, et al. Antimicrobial and anti-quorum sensing activity of some wild mushrooms collected from Turkey. MSU J of Sci. 2017;5(2):453-457.

8. Yilmaz A, Yildiz S, Çelik A, et al. Determination of heavy metal and radioactivity in Agaricus campestris mushroom collected from kahramanmaraş and erzurum proviences. Turkish Journal of Agriculture Food Science and Technology. 2016;4(3):208-215. 
9. Akgul H, Sevindik M, Coban C, et al. New Approaches in traditional and complementary alternative medicine practices: auricularia auricula and trametes versicolor. J Tradit Med Clin Natur. 2017;6:239.

10. Sevindik M, Akgul H, Korkmaz AI, et al. (2018) Antioxidant potantials of Helvella leucomelaena and Sarcosphaera coronaria. J Bacteriol Mycol Open Access. 6(2):00173.

11. Sevindik M, Akgul H, Bal C. Determination of oxidative stress status of ompholatus olearius gathered from adana and antalya provinces in Turkey. Sakarya Unvversity Journal of Science. 2017;21(3):324-327.
12. Sevindik M, Akgul H, Dogan M, et al. Determination of antioxidant, antimicrobial, DNA protective activity and heavy metals content of Laetiporus sulphureus. Fresenius Environmental Bulletin. 2018;27(3):1946-1952.

13. Sevindik M, Akgul H, Akata I, et al. Fomitopsis pinicola in healthful dietary approach and their therapeutic potentials. Acta Alimentaria. 2017;46(4):464-469. 